\title{
Comparison of the Frequency and Severity of Depression Between Patients with Stage 4 and 5 Chronic Kidney Disease with and Without Kidney Transplantation
}

\author{
Böbrek Nakli Olmuş ve Olmamış Evre 4 ve 5 Kronik Böbrek Hastalığı Olan \\ Olgularda Depresyon Sıklığı ve Şiddetinin Karşılaştırılması \\ ๑ Ilter Bozacı, ๑ Erhan Tatar \\ Bozyaka Training and Research Hospital, Clinic of Nephrology, Izmir, Turkey
}

Abstract

Aim: Patients with chronic kidney disease (CKD) are at an increased risk for depression. In the present study, we aimed to compare the frequency and severity of depression and its' association with demographical and laboratory parameters between stage 4 and 5 CKD patients with and without kidney transplantation.

Methods: The study included stage 4 and stage 5 CKD patients not on dialysis. The patients were separated into two groups. Group 1 was composed of patients with renal transplantation and group 2 was composed of patients without renal transplantation. The prevalence of depression was evaluated using the Beck Depression Inventory.

Results: Forty-nine patients were in group 1 and 52 patients in group 2. The mean depression score in group 1 was statistically significantly higher than in group $2(16 \pm 15$ vs $13.5 \pm 10$; $p=0.031)$. We found that depression score was correlated with parathormone levels $(p=0.023)$ and serum ferritin levels $(p=0.019)$. In multivariate linear regression analysis, depression scores were independently associated with parathormone [Exp (B): 0.997 (confidence interval $(\mathrm{Cl})$ : 0.995-1.0); $\mathrm{p}=0.023$ ] and ferritin [ $\operatorname{Exp}(B): 0.996$ (Cl: 0.994-0.998); $p=0.01$ ].

Conclusion: Higher prevalence of depression in patients with CKD who received renal transplantation is a significant finding. Routine psychiatric evaluation should become a part of follow-up and treatment in both groups.

Keywords: Chronic kidney disease, depression, transplantation
Amaç: Kronik böbrek hastalarında $(\mathrm{KBH})$ depresyon riski artmıştır. Bu çalışmamızda böbrek nakli olmuş ve olmamış evre 4 ve evre 5 kronik böbrek hastalığı olan olgularda depresyon sıklığı ve şiddetinin karşılaştırımasını amaçladık.

Yöntemler: Çalışmaya evre 4 ve evre 5 kronik böbrek hastalığı olup diyalize girmeyen hastalar dahil edildi. Hastalar, daha önce böbrek nakli olanlar grup 1; olmamış olanlar ise grup 2 olacak şekilde iki gruba ayrıldı. Hastaların depresyon sıklıklarının değerlendirilmesi amacıyla Beck Depresyon Envanteri kullanıldı.

Bulgular: Grup 1 49, grup 2 ise 52 hastadan oluşmaktaydı. Depresyon skorları açısından, grup 1'de daha yüksek olmak üzere iki grup arasında istatistiksel olarak anlamlı farklılık tespit

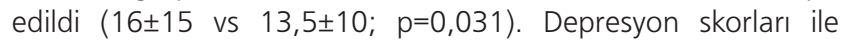
parathormon $(p=0,023)$ ve ferritin seviyeleri $(p=0,019)$ arasında korelasyon tespit edildi. Çoklu lineer regresyon analizinde depresyon skorlarının parathormon $[\operatorname{Exp}(B): 0,997$ güven aralığı $(G A): 0,995-1,0) ; p=0,023]$ ve ferritin düzeyleri ile $[\operatorname{Exp}(B): 0,996$ (GA: 0,994-0,998); $p=0,01]$ bağımsız ilişkili olduğu tespit edildi.

Sonuç: Böbrek nakli olmuş $\mathrm{KBH}^{\prime}$ lerdeki daha yüksek depresyon sıklığı önemli bir bulgudur. Rutin psikiyatrik değerlendirme, her iki hasta grubunda takip ve tedavinin bir parçası olmalıdır.

Anahtar Sözcükler: Kronik böbrek hastalığı, depresyon, transplantasyon
Address for Correspondence/Yazışma Adresi: Ilter Bozacı, Bozyaka Training and Research Hospital, Clinic of Nephrology, İzmir, Turkey E-mail: ilterbozaci@gmail.com ORCID: orcid.org/0000-0001-7535-9403 Received/Geliş Tarihi: 29 April 2020 Accepted/Kabul Tarihi: 20 August 2020
${ }^{0}$ Copyright 2020 by The Medical Bulletin of istanbul Haseki Training and Research Hospital The Medical Bulletin of Haseki published by Galenos Yayınevi. ${ }^{\circledR}$ Telif Hakkı 2020 istanbul Haseki Eğitim ve Araştırma Hastanesi Haseki Tıp Bülteni, Galenos Yayınevi tarafından yayınlanmıştır. 


\section{Introduction}

Depression is the most common psychiatric disorder in the general population (1). Patients with depression have an increased risk of mortality relative risk (1.81) (2). Untreated depression has been found to be associated with poor physiological outcomes when accompany with chronic medical conditions (3). Psychiatric illnesses, including depression, are common among patients with end stage renal disease (ESRD) (4). In the ESRD era, studies and guidelines are generally seemed to focus on patients on dialysis. To ensure the identification of depression, the Kidney Disease Outcomes Quality Initiative guidelines suggest that every dialysis patient should be evaluated by the dialysis social worker upon initiation of dialysis and at least biannually subsequently (5). There are various screening instruments for depression. In a metaanalysis of screening instruments in primary care, the median sensitivity and specificity of instruments was 85 and 74 percent respectively, with no significant difference in performance between instruments (6). The Beck Depression Inventory (BDI) is one of the screening tools used for the initial screening (7). The BDI consists of 21 items and can be applied to patients ranging in age from 10 years to the elderly (8). Regardless of etiology, patients with chronic kidney disease (CKD) are at an increased risk for depression. Although there are various guidelines for dialysis patients in terms of depression approach, there are no guidelines or clear recommendations for patients with CKD in whom dialysis is not initiated yet.

In the present study, we aimed to investigate the frequency and severity of depression and its' association with demographical and laboratory parameters in patients with stage 4 and 5 CKD and compare the results between those with and without kidney transplantation.

\section{Methods}

\section{Study Design}

This study was conducted in the nephrology outpatient clinic at a training and research hospital over 1-year period. The study was approved by the institutional ethics committee (no: 15345870, date: 12.5.2020). The study included stage 4 and stage 5 CKD patients, not on dialysis (9), who were older than 18 years and agreed to participate in the study after providing written informed consent. The patients were separated into two groups. Group 1 was composed of patients with renal transplantation and group 2 was composed of patients without renal transplantation. Those who were intellectually incapable of responding to the questionnaires or who declined to participate were excluded. A general questionnaire was used to obtain demographic information (age, gender) as well as data about number of comorbidities, use of antidepressants, immunosuppressive drugs and other medications.

We also analyzed the results of the most recent biochemical tests [glucose, urea, creatinine, estimated glomerular filtration ratio, sodium, potassium, calcium, phosphorus, albumin, uric acid, ferritin, parathormone (PTH), glycolyzed hemoglobin and bicarbonate levels] and complete blood count. To evaluate the prevalence of depression, the BDI was applied. A single examiner administered the questionnaires to the patients on the day they attended the outpatient clinic, keeping all information confidential and not disturbing their routine. This inventory is a questionnaire that consists of 21 individual items. Total score for depression is between 0 and 63. Minimal, mild, moderate and severe grades are assigned for scores of 0-9, 10-16, 17-29 and 30-63 respectively.

GFR was estimated from the serum creatinine using the CKD Epidemiology Collaborative Study Equation (10).

Kidney function stage was based on the Kidney Disease Improving Global Outcomes Clinical Practice Guideline (11).

\section{Statistical Analysis}

All statistical analyses were performed using the SPSS software (SPSS Inc., Chicago, IL, USA, version 18.0). Numerical variations were represented as mean \pm standard deviation, categorical variables were given as numbers and percentages. When comparing the groups, the chi-square test and Fisher's exact test were used for categorical variables. Comparison of two variables of numerical variables was done with the Student's t-test in case normal distribution condition was provided. Comparison of numerical variables between two groups was done using the Mann-Whitney $U$ test in cases where normal distribution condition was not met.

The degree of relationships of numerical variables with each other was evaluated by Pearson's correlation coefficient. Regression analysis was done to compare the effect of independent variables and the enter method was used for comparisons. In the correlation analysis, 0.100.29 low/weak, 0.30-0.49 medium degree, 0.50-1.00 strong correlation was accepted. The significance level was $p<0.05$.

\section{Results}

A total of 101 patients were enrolled in the study. Forty-nine patients were in group 1 and 52 in group 2. Twenty-nine of 49 patients (51\%) in group 1 and 30 of 52 patients (57\%) in group 2 were female. There was no statistically significant difference between the groups in terms of age and gender.

The etiologies of the patients were as follows: type 2 diabetes mellitus (DM) in 13 patients (27\%) in group 1 and 
eight patients in group 2 (15\%), essential hypertension in 41 patients (83\%) in group 1 and 49 patients in group 2 (94\%), and unknown etiology in eight patients (16\%) in group 1 and three patients (6\%) in group 2.

The demographic characteristics and laboratory results of group 1 and group 2 patients are presented in Table 1 .

There was a significant difference in biochemical parameters, such as serum glucose $(87 \pm 13 \mathrm{mg} / \mathrm{dL}$ vs $97 \pm 28 \mathrm{mg} / \mathrm{dL} ; \mathrm{p}=0.001)$, sodium $(137 \pm 3.3 \mathrm{mmol} / \mathrm{L}$ vs $138 \pm 2.9 \mathrm{mmol} / \mathrm{L} ; p=0.048) ;$ potassium $(4.3 \pm 0.7 \mathrm{mmol} / \mathrm{L}$ vs $4.6 \pm 0.6 \mathrm{mmol} / \mathrm{L} ; p=0.046)$ and ferritin $(377.7 \pm 599 \mathrm{ng} /$ $\mathrm{mL}$ vs $73.6 \pm 126 \mathrm{ng} / \mathrm{mL} ; \mathrm{p}=0.001$ ) between group 1 and group 2.

The mean depression score in group 1 was statistically significantly higher than in group $2(16 \pm 15$ vs $13.5 \pm 10$; $\mathrm{p}=0.031$ ). Depression scores in group 1 and group 2 are presented in Figure 1.

According to the depression scores, $20.4 \%$ of patients in group 1 had minimal depression, 36.7\% - mild depression, $26.5 \%$ - moderate depression and $16.3 \%$ of patients had severe depression.

\begin{tabular}{|c|c|c|c|}
\hline & $\begin{array}{l}\text { Group } 1 \\
(n=49)\end{array}$ & $\begin{array}{l}\text { Group } 2 \\
(n=52)\end{array}$ & $\mathbf{p}$ \\
\hline Age (years) & $41 \pm 17$ & $48.5 \pm 26$ & 0.188 \\
\hline Gender, F/M (\%) & $59 / 41$ & $57 / 43$ & 0.879 \\
\hline Glucose (mg/dL) & $87 \pm 13$ & $97 \pm 28$ & 0.001 \\
\hline Urea (mg/dL) & $98 \pm 72$ & $98 \pm 47$ & 0.521 \\
\hline Creatinine (mg/dL) & $3.9 \pm 2.1$ & $3.8 \pm 1.2$ & 0.900 \\
\hline eGFR $\left(\mathrm{mL} / \mathrm{min} / 1.73 \mathrm{~m}^{2}\right)$ & $19 \pm 11.2$ & $19.5 \pm 11.7$ & 0.804 \\
\hline $\mathrm{Na}(\mathrm{mmol} / \mathrm{L})$ & $137 \pm 3.3$ & $138 \pm 2.9$ & 0.048 \\
\hline $\mathrm{K}(\mathrm{mmol} / \mathrm{L})$ & $4.39 \pm 0.74$ & $4.67 \pm 0.65$ & 0.046 \\
\hline $\mathrm{Ca}(\mathrm{mg} / \mathrm{dL})$ & $9.1 \pm 1.2$ & $9.4 \pm 0.9$ & 0.065 \\
\hline$P(\mathrm{mg} / \mathrm{dL})$ & $4.1 \pm 1.5$ & $4.1 \pm 1.34$ & 0.935 \\
\hline Uric Acid (mg/dL) & $7.61 \pm 1.97$ & $7.64 \pm 1.87$ & 0.930 \\
\hline Albumin (g/dL) & $3.9 \pm 0.6$ & $4 \pm 0.65$ & 0.249 \\
\hline $\mathrm{HCO}_{3}(\mathrm{mmol} / \mathrm{L})$ & $20 \pm 4.3$ & $20 \pm 2.7$ & 0.709 \\
\hline Hemoglobin $(g / d L)$ & $10.8 \pm 1.4$ & $11 \pm 1.6$ & 0.585 \\
\hline Hematocrit (\%) & $34 \pm 4.4$ & $34 \pm 4.6$ & 0.934 \\
\hline Platelet $\left(\times 10^{3} / \mu \mathrm{L}\right)$ & $230 \pm 81$ & $260 \pm 99$ & 0.104 \\
\hline WBC $\left(x 10^{3} / \mu \mathrm{L}\right)$ & $7.7 \pm 2.6$ & $8.4 \pm 2.8$ & 0.220 \\
\hline${ }^{\#} \mathrm{Ne}\left(x 10^{3} / \mu \mathrm{L}\right)$ & $5.1 \pm 2.2$ & $5.5 \pm 2.04$ & 0.383 \\
\hline${ }^{\# L y}\left(x 10^{3} / \mu \mathrm{L}\right)$ & $1.6 \pm 0.7$ & $1.8 \pm 0.6$ & 0.172 \\
\hline Ferritin (ng/mL) & $377.7 \pm 599$ & $73.6 \pm 126$ & 0.001 \\
\hline PTH (pg/mL) & $333.3 \pm 580$ & $163.9 \pm 160$ & 0.058 \\
\hline Depression score & $16 \pm 15$ & $13.5 \pm 10$ & 0.031 \\
\hline \multicolumn{4}{|c|}{$\begin{array}{l}\text { F: Female, M: Male, eGFR: Estimated glomerular filtration ratio, WBC: White blood } \\
\text { cell count, \#Ne: Absolute neutrophil count, \#Ly: Absolute lymphocyte count, Na: } \\
\text { Sodium, K: Potassium, Ca: Calcium, P: Phosphorus; PTH: Parathormone, } \mathrm{HCO}_{3} \text {, } \\
\text { Bicarbonate, n: Number }\end{array}$} \\
\hline
\end{tabular}

On the other hand, the distribution of patients in group 2 according to the depression scores for minimal, mild, moderate and severe depression were $34.6 \%, 23.1 \%$, $40.4 \%$ and $1.9 \%$ respectively. A statistically significant difference in depression scores was also found between group 1 and group 2 even if minimal groups were considered normal $(p=0.016)$. Distribution of depression scores in group 1 and group 2 is presented at Table 2 .

Antidepressant usage frequencies were $12 \%$ and $6 \%$ for group 1 and group 2, respectively.

Also, depression scores were not statistically significantly different between patient groups who were and were not using antidepressant medications $(14 \pm 20$ vs $14.5 \pm 12 ; p=0.519$ ).

A total of 21 patients were diagnosed with DM and treated. Comparison of patients with and without DM in terms of depression score revealed no significant difference ( $15.1 \pm 8$ vs $14 \pm 9 ; p=0.606)$. On the other hand, a total of 90 patients were diagnosed with essential hypertension and treated. Comparison of patients with and without essential hypertension in terms of depression score revealed a statistically significant difference (16 11 vs $10 \pm 7 ; p=0.043$ ) as well.

Correlation analysis between depression score and laboratory parameters revealed a correlation with PTH levels and serum ferritin levels (Table 3 ).

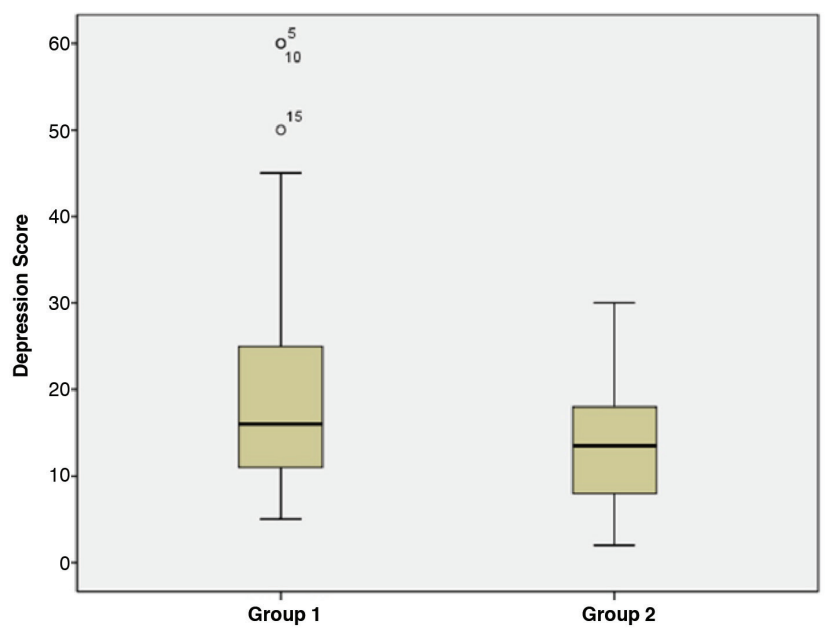

Figure 1. Depression scores of group 1 and group 2

\begin{tabular}{|c|c|c|c|}
\hline Depression score & $\begin{array}{l}\text { Group } 1 \\
(n=49)\end{array}$ & \begin{tabular}{|l|}
$\begin{array}{l}\text { Group } 2 \\
(n=52)\end{array}$ \\
\end{tabular} & $p$ \\
\hline Minimal (0-9) & $10(20.4 \%)$ & $18(34.6 \%)$ & \multirow{4}{*}{0.013} \\
\hline Mild (10-16) & $18(36.7 \%)$ & $12(23.1 \%)$ & \\
\hline Moderate (17-29) & $13(26.5 \%)$ & $21(40.4 \%)$ & \\
\hline Severe (30-63) & $8(16.3 \%)$ & $1(1.9 \%)$ & \\
\hline \multicolumn{4}{|l|}{$\mathrm{n}$ : Number } \\
\hline
\end{tabular}


In multivariate linear regression analysis (variables: age, gender, PTH, calcium, phosphorus, ferritin and hemoglobin) depression scores were independently associated with PTH [Exp (B): 0.997 (confidence interval $(\mathrm{Cl}): 0.995-1.0) ; \mathrm{p}=0.023]$ and ferritin $[\operatorname{Exp}(\mathrm{B}): 0.996(\mathrm{Cl}$ : 0.994-0.998); $p=0.01]$.

\section{Discussion}

In this study, we found higher frequencies of depression in patients of group 1 compared to group 2 (79.6\% vs $66.4 \%)$. The frequency of moderate and severe depression was higher in group 1. We found a positive correlation between PTH and ferritin levels and depression scores. We also found that PTH levels and ferritin levels were independently associated with depression scores.

The frequency of depression in group 2 was found to be $66.4 \%$ in our study. It was comparable to that of study by Shafi and Shafi (9) in which they compared patients with CKD not on dialysis with hemodialysis patients. They found a frequency of depression of $64.9 \%$ in patients with stage 4 and 5 CKD not on dialysis. Driessen et al. (12) investigated and found an association between depression

\begin{tabular}{|c|c|c|}
\hline & \multicolumn{2}{|c|}{ Depression Score } \\
\hline & $\mathrm{Rh}_{0}$ & $p$ \\
\hline Age (years) & -103 & 0.307 \\
\hline Glucose (mg/dL) & -0.076 & 0.452 \\
\hline Urea (mg/dL) & -0.087 & 0.389 \\
\hline Creatinine (mg/dL) & -0.115 & 0.251 \\
\hline eGFR $\left(\mathrm{mL} / \mathrm{min} / 1.73 \mathrm{~m}^{2}\right)$ & 0.075 & 0.457 \\
\hline $\mathrm{Na}(\mathrm{mmol} / \mathrm{L})$ & 0.003 & 0.979 \\
\hline $\mathrm{K}(\mathrm{mmol} / \mathrm{L})$ & -0.153 & 0.126 \\
\hline $\mathrm{Ca}(\mathrm{mg} / \mathrm{dL})$ & 0.024 & 0.815 \\
\hline$P(\mathrm{mg} / \mathrm{dL})$ & 0.087 & 0.389 \\
\hline Uric Acid (mg/dL) & 0.002 & 0.988 \\
\hline Albumin (g/dL) & -0.084 & 0.405 \\
\hline $\mathrm{HCO}_{3}(\mathrm{mmol} / \mathrm{L})$ & -0.055 & 0.585 \\
\hline Hemoglobin $(\mathrm{g} / \mathrm{dL})$ & 0.153 & 0.126 \\
\hline Hematocrit (\%) & 0.170 & 0.089 \\
\hline Platelet $\left(\times 10^{3} / \mu \mathrm{L}\right)$ & -0.089 & 0.376 \\
\hline WBC $\left(\times 10^{3} / \mu \mathrm{L}\right)$ & 0.081 & 0.419 \\
\hline$\# \mathrm{Ne}\left(\times 10^{3} / \mu \mathrm{L}\right)$ & 0.140 & 0.161 \\
\hline \#Ly $\left(x 10^{3} / \mu \mathrm{L}\right)$ & -0.006 & 0.954 \\
\hline Ferritin (ng/mL) & 0.232 & 0.019 \\
\hline PTH (pg/mL) & 0.225 & 0.023 \\
\hline HbA1c (\%) & 0.192 & 0.404 \\
\hline \multicolumn{3}{|c|}{$\begin{array}{l}\text { eGFR: Estimated glomerular filtration ratio, WBC: White blood cell count, N } \\
\text { Sodium, K: Potassium, Ca: Calcium, P: Phosphorus, PTH: Parathormone, } \mathrm{HbA} 1 \\
\text { Hemoglobin } \mathrm{Alc}_{1} \mathrm{HCO}_{3} \text { : Bicarbonate, \#Ne: Absolute neutrophil Count, \#L } \\
\text { Absolute lymphocyte count }\end{array}$} \\
\hline
\end{tabular}

and secondary hyperparathyroidism in chronic renal failure. In our study, we found a statistically significantly difference in PTH levels between group 1 and group 2. A positive correlation was detected between PTH levels and depression scores as well. This might have contributed to the frequency and severity of depression in group 1 .

In the literature, Afsar and Elsurer (13) investigated the association between serum bicarbonate and $\mathrm{pH}$ levels and depression, cognition and sleep quality in hemodialysis patients. Metabolic acidosis and bicarbonate levels were found to be independently associated with sleep quality. They also found no association between bicarbonate levels and depression. Although the properties of patient population were not exactly the same as our patient population, we found no statistically significant difference between the groups in terms of bicarbonate levels. We also found no correlation between depression score and bicarbonate levels. This might be the consequence of appropriate treatment of metabolic acidosis in our patient population.

The American Psychiatric Association Diagnostic and Statistical Manual of Mental Disorders defined DM as a mood disorder that reunites several symptoms that alter the functionality of an individual (14). Diabetes and depression reduce the quality of life of an individual, especially their negative impact increases when they exist at the same time (15). Both diseases should be recognized in an individual and treated simultaneously in order to reduce depression and better control diabetes. Depression is thought to be under-diagnosed and undertreated in diabetic patients (16).

There was no statistically significant difference in depression scores between patients with DM and patients with essential hypertension. This might be the result of the limited number of patients.

We found higher frequency of antidepressant use in group 1 compared to group 2. This might be associated with higher awareness in patients who received renal transplantation. Also, this might be the result of higher frequency of severe depression and the need for treatment in group 1. On the other hand, in our study, most of the patients in group 1 had previously been on dialysis. Although the data about the duration of hemodialysis in group 1 could not be reached due to insufficient medical records, the possibility of living the same poor experiences might have contributed to the severity of depression in the CKD patients with renal transplantation.

Maintenance immunosuppressive therapy is administered in almost all kidney transplant recipients to prevent acute rejection and loss of renal allograft. The major immunosuppressive agents that are available in various combination regimens are glucocorticoids (primarily 
prednisone), azathioprine, mycophenolate mofetil (MMF), cyclosporine, tacrolimus, everolimus, rapamycin (sirolimus) and belatacept (17). The immunosuppressive benefits derived from these agents are counterbalanced by the possible induction of numerous major adverse effects. In our study, patients in group 1 were mostly on prednisone + MMF + tacrolimus therapy. Primarily glucocorticoids are known to have neuropsychiatric adverse effects including depression (18). Medications used for immunosuppression, particularly glucocorticoids, might have played a role in higher frequencies and severity rated of depression in group 1.

We found a significant difference in depression score between CKD patients with and without renal transplantation. On the other hand, it was concluded in the Psychiatric Impairments in Kidney Transplantation Study that kidney transplantation itself does not appear to be the main risk factor for the development of mental impairments (19). Anxiety of starting dialysis again in group 1 might have contributed to this situation in our study.

Anemia was found to be associated with depression in several studies even in healthy individuals $(20,21)$. We found no statistically significant difference between groups in terms of hemoglobin levels; the mean levels were low in both groups, though. Besides, we found no correlation between depression scores and serum hemoglobin levels. Nevertheless, correction of anemia in patients with CKD should be considered during the treatment of depression. In their study, Okan et al. (22) investigated the association between ferritin levels and depression and found higher depression levels in the low ferritin level group although it was not found statistically significant. However, we found high ferritin levels in both groups and higher levels in group 1, in which depression scores were also higher. Also, we found that serum ferritin levels were independently associated with depression score. Serum ferritin is recognized as an acute phase reactant and marker of acute and chronic inflammation and is nonspecifically elevated in a wide range of inflammatory conditions, including CKD (23). Also, a relationship between inflammation and depression has been shown in the literature (24). The higher levels of ferritin in group 1 might be due to either higher incidence of previous transfusions or difference in severity of inflammation between the groups.

Depression is an important disorder that affects the quality of life via various ways. Czyzewski et al. (25) found an association between depression and quality of life in patients after kidney transplantation. One of the most important issues in terms of graft function in transplant recipients is adherence. Villeneuve et al. (26) found that good adherence was associated with fewer depression episodes. Early detection of depressive episodes in patients with CKD may contribute to adherence in transplant recipients and contribute to graft survival.

\section{Study Limitations}

It is a single-center study with limited sample size. We used only one inventory to screen depression in our outpatient population rather than structured clinical interview by a qualified psychiatrist. There was no control group as well. The duration of dialysis in most of the patients in group 2 could not be detected due to insufficient data in medical records.

\section{Conclusion}

To conclude, higher prevalence of depression in patients with CKD who received renal transplantation is a significant finding. Many different factors might play a role in this situation. It is clear that routine approaches involving monitoring laboratory results and treatment modifications are not sufficient to maintain renal function and ensure patient survival. Appropriate psychological follow up and support should be provided and routine psychiatric evaluation should become a part of follow-up and treatment in both groups.

\section{Authorship Contributions}

Surgical and Medical Practices: I.B., E.T. Concept: I.B., E.T. Design: I.B. Data Collection or Processing: I.B., E.T. Analysis or Interpretation: I.B., E.T. Literature Search: I.B., E.T. Writing: I.B.

Conflict of Interest: No conflict of interest was declared by the authors.

Financial Disclosure: The authors declared that this study received no financial support.

\section{References}

1. Kessler RC, Ormel J, Petokhova M, et al. Development of lifetime comorbidity in the World Health Organization World mental health surveys. Arch Gen Psychiatry 2011;68:90.

2. Cuijpers P, Smit F. Excess mortality in depression: a meta-analysis of community studies. J Affect Disord 2002;72:227.

3. Moussavi S, Chatterji S, Verdes E, et al. Depression, chronic diseases and decrements in health: results from the World Health Surveys. Lancet 2007;370:851.

4. Kimmel PL, Thamer M, Richard CM, Ray NF. Psychiatric illness in patients with end-stage renal disease. Am J Med 1998;105:214.

5. K/DOQI Workgroup. K/DOQI clinical practice guidelines for cardiovascular disease in dialysis patients. Am J Kidney Dis 2005;45:S1. 
6. Williams AJ, Pignone M, Ramirez G, Perez Stellato C. Identifying depression in primary care: a literature synthesis of case-finding instruments. Gen Hosp Psychiatry 2002;24:225.

7. Cohen SD, Norris L, Acquaviva K, et al. Screening, diagnosis and treatment of depression in patients with end-stage renal disease. Clin J Am Soc Nephrol 2007;2:1332.

8. Grant D, Almond M.K, Newnham A, Roberts P, Hutchings A. The Beck Depression Inventory requires modification in scoring before use in a hemodialysis population in the UK. Nephron Clinical Practice 2008;110:33-8.

9. Shafi ST, Shafi TA. Comparison of anxiety and depression between pre-dialysis chronic kidney disease patients and hemodialysis patients using hospital anxiety and depression scale. Pak J Med Sci 2017;33:876-80.

10. Levey AS, Stevens LA, Schmid $C H$, et al. A new equation to estimate glomerular filtration rate. Ann Intern Med 2009; 150:604-12.

11. Andrassy KM. Improving global outcomes (KDIGO) CKD Work Group. KDIGO 2012 Clinical practice guideline for the evaluation and management of chronic kidney disease. Kidney Inter 2013;84:622-3.

12. Driessen M, Wetterling $T$, Wedel T, Preuss R. Secondary hyperparathyroidism and depression in chronical renal failure. Nephron 1995;70:334-9.

13. Afsar B, Elsurer R. Association between serum bicarbonate and $\mathrm{pH}$ with depression, cognition and sleep quality in hemodialysis patients. Renal Failure 2015;37:957-60.

14. American Psychiatric Association, Task F. Diagnostic and statistical manual of mental disorders DSM-5. Fifth edition; 2013.

15. Schram MT, Baan CA, Pouwer F. Depression and quality of life in patients with diabetes: a systematic review from the European depression in diabetes (EDID) research consortium. Curr Diabetes Rev 2009;5:112-9.

16. Li C, Ford ES, Zhao G, Ahluwalia IB, Pearson WS, Mokdad $\mathrm{AH}$. Prevalence and correlates of undiagnosed depression among U.S. adults with diabetes: the Behavioral Risk
Factor Surveillance System 2006. Diabetes Res Clin Pract 2009;83:268-79.

17. Halloran PF. Immunosupressive drugs for kidney transplantation. N Engl J Med 2004;351:2715.

18. Wolkowitz OM, Burke H, Epel ES, Reus VI. Glucocorticoids. Mood, memory and mechanisms. Ann N Y Acad Sci 2009;1179:19-40.

19. Muller HH, Englbrecht M, Wiesener MS, et al. Depression, anxiety, resilience and coping pre and post kidney transplantation- Initial findings from the Psychiatric Impairments in Kidney Transplantation (PI-KT) Study. PLoS ONE 2015;10: e0140706.

20. Vulser $H$, Wiernik $E$, Hoertel $N$, et al. Association between depression and anemia in otherwise healthy adults. Acta Psychiatr Scand 2016;134:150-60.

21. Association between iron-deficiency anemia and depression: A web-based Japanese investigation. Psyhiatry and Clinical Neurosciences 2018;72:513-21.

22. Okan S, Turk AÇ, Sıvgın H, Ozsoy F, Okan F. Association of ferritin levels with depression, anxiety, sleep quality, and physical functioning in patients with fibromyalgia syndrome: a cross-sectional study. Croat Med J 2019;60:515-20.

23. Kalantar-Zadeh K, Kalantar-Zadeh K, Lee GH. The fascinating but deceptive ferritin: to measure it or not to measure it in chronic kidney disease? Clin J Am Soc Nephrol 2006;1:9-18.

24. Dantzer R, O'connor JC, Freund GG, Johnson RW, Kelley $\mathrm{KW}$. From inflammation to sickness and depression: when the immune system subjugates the brain. Nat Rev Neurosci 2008;9:46-56.

25. Czyzewski L, Frelik P, Wyzgal J, Szarpak L. Evaluation of quality of life and severity of depression, anxiety and stress in patients after kidney transplantation. Transplant Proc 2018;50:17337.

26. Villeneuve $C$, Rousseau A, Rerolle JP, et al. Adherence profiles in kidney transplant patients: Causes and sonsequences. Patient Educ Couns 2020;103:189-98. 